\section{Penulis Karya Ilmiah dan Copyediting}

\author{
Sugihastuti \\ Indonesian Language and Literature Study Program \\ Universitas Gadjah Mada \\ sugihastuti@ugm.ac.id
}

\begin{abstract}
ABSTRAK
Tulisan ini berlatar belakang sebagai berikut. Satu hal yang patut menjadi perhatian penulis dan proses penerbitan karya ilmiah adalah edit, yaitu memperbaiki naskah atau menyunting naskah. Kata kerja edit menjadi hal yang penting dalam proses pengeditan sebelum penulis menerbitkannya. Editor, dengan demikian, menjadi orang yang penting juga dalam mengedit naskah tulisan atau karangan yang akan diterbitkan. Orang dapat menyebutnya sebagai pengedit atau penyuting. Dalam hal yang lebih spesifik, editor bahasa diperlukan dalam penyuntingan naskah. Editor bahasa bekerja untuk menyunting naskah yang akan diterbitkan dengan memperhatikan ejaan, diksi, dan struktur kalimat. Tidak hanya dalam hal itu, berbagai hal tentang penyuntingan naskah dilakukan oleh penyunting naskah, termasuk editor bahasa; lalu bagaimanakah perihal penyuntingan naskah (copyediting)?
\end{abstract}

Masalah yang muncul dalam tulisan ini, antara lain, adalah perihal copyediting. Bagaimana copyediting dapat dilakukan dengan efektif dan efisien?

Berdasar pada teori kebahasaan beserta kaidah-kaidah teknik penulisan ilmiah, metode tulisan ini merupakan metode deskriptif-kualitatif tentang copyediting. Ada (a) aspek-aspek yang diedit, (b) proses pengeditan yang cerdas, (c) prinsip kerja pengeditan, (d) peralatan pengeditan, (e) dan peringatan untuk editor bahasa.

Hasil akhir tulisan ini merupakan masukan bagi penulis karya ilmiah. Masukan-masukan itu, antara lain, berupa hal-hal yang berkaitan dengan teks-naskah, format naskah, jenis pengeditan, gaya selingkung, dan detail administrasi.

Kata kunci: penulis karya ilmiah; editor; copyediting

\title{
PENDAHULUAN
}

Tidak dapat dimungkiri lagi bahwa penulis karya ilmiah pada kelanjutannya akan menerbitkan tulisannya. Dalam proses menulis sampai ke penerbitan tulisan, ada beberapa hal yang berkait dengannya. Salah satu hal itu adalah edit, perbaiki naskah, atau sunting naskah. Kata kerja edit berkata-turunan mengedit, yaitu mempersiapkan naskah yang siap cetak atau siap terbit, dengan memperhatikan terutama segi ejaan, diksi, dan struktur kalimat. Mengedit juga merupakan langkah merencanakan dan mengarahkan penerbitan. Dalam bidang film dan pita rekaman, misalnya, mengedit artinya menyusun dengan memotong dan memadukannya kembali. Sinonim kata mengedit adalah menyunting. Proses, cara, dan perbuatan mengedit disebut pengeditan atau penyuntingan.

Orang yang mengedit naskah tulisan atau karangan yang akan diterbitkan disebut editor, pengedit, atau penyunting. Lain halnya dalam bidang komputer, editor artinya program yang berfungsi menciptakan berkas atau membuat perubahan pada berkas yang sudah ada. Gabungan kata dari kata editor adalah editor bahasa, editor pengelola, dan editor penyelia. Editor bahasa adalah penyunting naskah yang akan diterbitkan dengan memperhatikan ejaan, diksi, dan struktur kalimat. Editor pengelola adalah petugas yang bertanggung jawab atas penyampaian berita di televisi dan radio; pada surat kabar dan majalah disebut redaktur pelaksana. Editor penyelia adalah manajer penyunting yang bertanggung jawab atas pelaksanaan tugas para penyunting secara tepat dan efisien sesuai dengan yang telah ditentukan. 
Tulisan ini membatasi diri pada peran penulis karya ilmiah yang mengedit tulisannya dan bersiap diri untuk menerbitkannya. Dengan demikian, selesai berperan sebagai penulis, dia berpindah peran sebagai editor bahasa naskah miliknya. Nah, dalam posisi sebagai editor bahasa naskah tulisannya, dia akan melakukan copyediting, yaitu penyuntingan naskah.

Dalam kaitannya dengan kode etik penulis, penulis dituntut untuk menjunjung tinggi posisi terhormatnya sebagai orang terpelajar, dengan jalan menjaga kebenaran hakiki, manfaat, dan makna informasi yang akan disebarluaskan sehingga tidak menyesatkan orang lain. Penulis dengan kesungguhan mengupayakan tulisan yang disajikannya tidak merupakan bahan yang menyusahkan untuk dibaca karena telah ditulisnya secara tepat, singkat, dan jelas (Rifai, 2005:5). Hanya saja, tulisan ini membatasi diri pada (a) aspek-aspek yang diedit dan (b) proses pengeditan yang cerdas. Tiga hal lain, yaitu (a) prinsip kerja pengeditan, (b) peralatan pengeditan, dan (c) peringatan untuk editor bahasa, secara inplisit ternarasikan ke dalam dua hal lain, yaitu aspek-aspek yang diedit dan proses pengeditan yangn cerdas.

Rumusan masalah tulisan ini adalah bagaimana copyediting dapat dilakukan oleh editor bahasa dengan efektif dan efisien?

Tujuan dituliskannya hal ini ada dua, yaitu tujuan teoretis dan tujuan praktis. Tujuan teoretis tulisan ini adalah untuk menjawab masalah keefektifan dan keefisienan copyediting. Tujuan praktisnya, antara lain, adalah (a) membekali penulis karya ilmiah untuk mampu dan piawai mengedit naskah miliknya, yaitu melakukan penyuntingan naskah, (b) membekali penulis karya ilmiah untuk mampu mengefektifkan copyediting, dan (c) membekali penulis karya ilmiah untuk mengefisienkan copyediting yang dilakukannya.

Sampai dewasa ini, masih saja ada segelintir penulis karya ilmiah yang menganggap sepele peran editor bahasa dalam copyediting. Senyampang seseorang membaca buku nonfiksi yang terbit apik, sering tidak terbayang olehnya bahwa di balik penerbitan yang elok itu ada peran editor bahasa dalam copyediting. Lebih elok lagi, peran editor bahasa itu dilakukan sendiri oleh penulis naskah.

Sudah ada sejumlah buku terbit tentang copyediting. Beberapa di antaranya adalah sebagai berikut. (1) Datus C Smith (1992) menulis Penuntun Penerbitan Buku, Jakarta: Pusat Grafika Indonesia. (2) Tim Grasindo (1994) menerbitkan Buku Pintar Penerbitan Buku, Jakarta: Grasindo. (3) Bambang Trimansyah (2002) menulis Menggagas Buku: Langkah Efektif dan Sistemik Menuliskan Ide Anda ke dalam Buku, Bandung: Bunaya dan pada 2005 menulis Memahami Copyediting, Jakarta: IKAPI DKI Jakarta. (4) Mien A. Rifai (2004) menulis Pegangang Gaya Pernulisan, Penyuntingan, dan Penerbitan Karya Ilmiah Indonesia, (5) Pamusuk Eneste (2005) menulis Buku Pintar Penyuntingan, Jakarta: Gramedia. (6) Sugihastuti (2016) menulis Editor Bahasa, Yogyakarta: Pustaka Pelajar. (7) Sugihastuti (2016) menulis Praktik Penyuntingan Kalimat, Yogyakarta: Pustaka Pelajar. Sejumlah buku terbit tentang copyediting ini dapat mengayakan penulis untuk mempu mengedit sendiri tulisannya. Tulisan ini merupakan pengingat ulang untuk penulis karya ilmiah agar mampu meng-copyediting tulisannya.

Untuk penulis mampu meng-copyediting tulisannya, sesuai dengan perannya sebagai editor bahasa, teori dasar kebahasaan, yang antara lain mengangkut ejaan, diksi, dan struktur kalimat, harus dikuasai. Selebihnya, penguasaan atas teori dasar kebahasaan itu diperkaya dengan teknik penulisan ilmiah beserta gaya selingkung penerbitannya.

Tulisan ini bermetode deskriptif-kualitatif. Contoh-contoh kesalahan yang pada umumnya dilakukan oleh penulis karya ilmiah dinarasikan dalam copyediting.

\section{DISKUSI}

Copyediting adalah langkah memberikan perhatian penuh pada setiap detail naskah berdasarkan pengetahuan atas apa yang sepantasnya ditampilkan dan berdasarkan gaya yang harus diikuti, serta mempu mengerjakannya dengan cepat, logis, dan keputusan yang menguatkan. Judd (via Trimansyah, 2005:30) ketika mempersiapkan naskah untuk bukunya, Copyediting, sempat menanyakan defisini copyediting kepada para managing editor dan copyeditor di beberapa negara. Berikut ini respons dari penerbit buku yang menjadi favoritnya. Copyediting merupakan peluang berjaya untuk mempersembahkan kreasi. Sesuatu yang sulit dipelajari adalah ketika membiarkan sesuatu apa adanya. Kesalahan yang tidak terampuni dalam copyediting adalah menghilangkan sesuatu yang benar, menggantinya dan membuatnya menjadi salah. Seorang copyeditor harus selalu 
menjadi penjaga dari gangguan yang tidak bertanggung jawab. Nah, copyeditor itulah yang seharusnya mampu diperankan oleh pada awalnya penulis naskah. Copyediting ini memfasilitasi kejelasan dan kepahaman melalui gaya menulis. Penulis naskah bertindak sendiri sebagai editor bahasa tulisannya.

Penyuntingan (editing) adalah aktivitas yang berkaitan dengan persiapan naskah untuk diterbitkan menjadi bahan publikasi. Orang yang melakukan pekerjaan editing disebut editor atau penyunting. Editor paling tidak harus memahami seluk-beluk dunia penulisan, pernaskahan, dan penerbitan (Trim, 2005:5). Seorang penulis yang menyunting sendiri naskah tulisannya terkategorikan sebagai copyeditor; ia memeriksa dan memperbaiki naskah (copyediting) sesuai dengan gaya selingkung penerbit dan kaidah yang berlaku.

Dalam hal yang paling mendasar, ejaan, penulis yang berperan editor bahasa sudah harus dengan sendirinya menguasai dan menerapkannya secara benar pada tulisan. Dalam hal (a) pemakaian huruf, (b) penulisan kata, (c) pemakaian tanda baca, dan (d) penulisan unsur serapan, editor bahasa sudah harus terampil menerapkannya. Pedoman Umum Ejaan Bahasa Indonesia menjadi modal alat kepiawaiannya.

\section{Pemakaian Huruf}

Huruf abjad, huruf vokal, huruf konsonan, huruf diftong, gabungan huruf konsonan, huruf kapital, huruf miring, dan huruf tebal pantas dicermati ketika menuliskannya dalam karya ilmiah. Huruf abjad dipastikan tidak salah ditulis oleh mereka. Dalam hal huruf vokal, ketika diperlukan, tidak usah segansegan untuk menuliskan diakritik demi penjelasan pengucapan (pelafalan) kata yang benar ketika diperlukan dalam penulisan karya ilmiah itu. Diakritik dapat digunakan jika ejaan kata itu dapat menimbulkan keraguan. Diakritik adalah tanda tambahan pada huruf yang sedikit banyak mengubah nilai fonetis huruf itu, misalnya tanda ['] pada e'.

Sepintas dalam pengamatan data naskah karya penulis karya ilmiah, hampir tidak dilakukan kesalahan pada penulisan huruf konsonan. Hanya saja, pada kata-kata tertentu, misalnya pada huruf /j/, penulis masih saja salah menuliskan kata mikraj, yang artinya adalah (1) perjalanan yang dilakukan Nabi Muhammad saw. dari Masjidilaksa ke Sidratulmuntaha (langit ke tujuh) pada malam hari yang intinya menerima perintah salat lima waktu dan (2) perjalanan yang dilakukan Nabi Muhammad saw. pada malam hari dari Masjidilaksa di Yerusalem hingga langit ke tujuh dan berakhir di Sidratulmuntaha (di atas langit ke tujuh).

Banyak kata salah ditulis karena kesalahan penulisan huruf konsonan, seperti terlihat pada contoh kata mikraj di atas. Selain itu, kata takraw yang berakhir dengan huruf konsonan /w/ juga sering salah dituliskan. Huruf konsonan w dapat ditulis pada posisi akhir sebuah kata. Kata takraw berarti bola yang terbuat dari anyaman rotan atau bola rotan. Ada huruf konsonan yang tidak dapat dituliskan pada akhir sebuah kata, yaitu /c/, /q/, /x/, dan /y/. Huruf konsonan / / juga tidak berada pada posisi di tengah kata. Huruf /q/ dan / / khusus digunakan untuk nama diri dan keperluan ilmu. Huruf / $/$ pada posisi awal kata diucapkan [s].

Yang perlu dicermati pada penulisan huruf diftong adalah tidak didapatinya huruf diftong /oi/ pada awal kata. Huruf diftong/ai/, /au/, /ei/ terletak di posisi awal, tengah, dan akhir kata. Huruf diftong/oi/ hanya terletak pada posisi tengah dan akhir kata.

Gabungan huruf konsonan /kh/, /ng/, /ny/ dan /sy/, yang masing-masing melambangkan satu bunyi konsonan, berposisi di awal, tengah, dan akhir kata; kecuali gabungan huruf konsonan /sy/ tidak terdapat pada posisi akhir kata. Dalam hal penulisan gabungan huruf konsonan, proses morfologinya sering salah. Misalnya, pada kata khayal, gabungan huruf konsonan /kh/ tidak luluh pada kata mengkhayal, demikian juga kata ngabat menjadi mengabat; artinya adalah mengikat atau mengebat. Di dalam budaya Dayak, kata mengabat berarti memanen padi yang mulai masak; digunakan untuk sesaji. Pada kata nyalang, gabungan huruf konsonan /ny/ tidak luluh sehingga bentukan kata turunannya menjadi, misalnya, menyalangkan; artinya adalah membelalakkan (mata), membuka (mata) lebar-lebar atau memandang dengan sinar mata yang tajam. Pada kata benda klasik syarikat, misalnya, gabungan huruf konsonan /sy/ tidak luluh pada mensyarikat; artinya adalah bersama-sama dalam kesusahan atau ikut serta. Gabungan huruf konsonan itu masing-masing melambangkan satu bunyi konsonan. 
Penulisan huruf kapital masih saja harus dicermati supaya tampilan tulisan berkaidah benar. Kaidahkaidah penulisan huruf kapital merupakan rumusan yang sudah pasti dan menjadi patokan kapan kata, frasa, dan kalimat itu berhuruf kapital atau bukan. Huruf kapital ini merupakan huruf yang berukuran dan berbentuk khusus (lebih besar daripada huruf biasa); biasanya digunakan sebagai huruf pertama dari kata pertama dalam kalimat, huruf pertama nama diri, dan sebagainya. Demikian juga halnya dengan huruf miring dan huruf tebal, keduanya berkaidah penulisan, seperti termuat dalam PUEBI.

\section{Penulisan Kata}

Dalam hal pembentukan kata, ada banyak kaidah yang perlu diperhatikan penulis; misalnya morfem, alomorf, kata dasar, analogi, proses morfofonemik, afiks, prefiks, sufiks, infiks, konfiks, afiks homofon, verba transitif dan taktransitif, dan keanggotaan ganda (Alwi dkk., 2014:28-35). Dalam hal penulisan kata dan pilihan kata (diksi), penulis karya ilmiah juga masih saja sesekali lena dalam berkaidah, seperti halnya penerapan tata huruf, kata, tanda baca, dan unsur serapan. Cermat berdiksi diperlukan karena diksi merupakan pilihan kata yang tepat dan selaras dalam penggunaannya untuk mengungkapkan gagasan sehingga diperoleh efek tertentu seperti yang diharapkan. Contoh, untuk mengungkapkan kata yang tepat dengan maksud berkecenderungan sangat suka atau tidak suka terhadap sesuatu makanan tanpa alasan khusus, tidak cukup ditulis tidak suka atau pokoknya tidak suka. Akan tetapi, diksi yang tepat untuk maksud itu adalah fadi.

Keterampilan berdiksi pantas diasah terus-menerus dalam berkarya ilmiah. Kata yang populer untuk mengartikan cerita bersambung di surat kabar adalah cerbung atau cerita bersambung. Kepiawaian berdiksi akan mengantarkan penulis untuk memilih kata feuilleton, yaitu cerita bersambung di surat kabar. Dalam ragam percakapan, misalnya, kata baku mode ditulis menjadi fesyen. Ada diksi fesyen jalanan, yaitu busana yang diciptakan dan dipakai oleh orang-orang muda bukan oleh perancang busana, sering dikaitkan dengan gaya populer musik dan tari atau subkultur urban.

Sudah seharusnya diperhatikan penulisan kata baku dan tidaknya. Kata-kata baku ini merupakan kata-kata yang standar, pokok, utama, dan menjadi tolok ukur yang berlaku untuk kuantitas atau kualitas yang ditetapkan berdasarkan kebakuan kata bahasa Indonesia. Baku tidaknya kata dapat dicek melalui Kamus Besar Bahasa Indonesia. Kata kopor, misalnya, yang akrab dalam keseharian merupakan bentuk tidak baku dari koper, yaitu peti yang terbuat dari kulit (kaleng dan sebagainya) tempat menyimpan pakaian yang dapat dibawa dalam perjalanan. Banyak sekali contoh kata tidak baku yang masih saja sering ditulis, yang tidak layak dideretkan di sini.

Tidak hanya sesederhana itu, penulisan kata ini menyangkut penulisan kata dasar, kata berimbuhan, bentuk ulang, gabungan kata, pemenggalan kata, kata depan, partikel, singkatan dan akronim, angka dan bilangan, kata ganti, dan kata sandang. Cukup banyak kaidah yang gayut dengannya. Penulis perlu cermat memperhatikannya.

Yang banyak dilewatkan oleh penulis adalah penulisan bentuk terikat. Bentuk terikat ini ditulis serangkai dengan kata yang mengikutinya; misalnya adibusana, aerodinamika, antarkota, antibiotik, awahama, bikarbonat, biokimia, dekameter, demoralisasi, dwiwarna, ekabahasa, ekstrakulikuler, infrastruktur, inkonvensional, kontraindikasi, kosponsor, mancanegara, multilateral, narapidana, nonkolaborasi, paripurna, pascasarjana, pramusaji, prasejarah, proaktif, purnawirawan, saptakrida, semiprofesional, subbagian, swadaya, telewicara, transmigrasi, tunakarya, tritunggal, tansuara, dan ultramodern.

Belum lagi penulisan kata-kata lain yang harus diperhatikan oleh penulis, misalnya kata bentukan (kata turunan), kata berimbuhan, kata majemuk, kata mubazir, kata penghubung, kata sandang, kata sapaan, kata serapan, kata seru, dan yang lain. Dalam hal kata berimbuhan, misalnya, diperhatikan penulisannya yang berkait dengan prefiks, infiks, sufiks, dan konfiks. Kata majemuk pun sesekali salah dituliskan, yang pada dasarnya kata majemuk itu ditulis terpisah. Kata majemuk ini merupakan gabungan morfem dasar yang seluruhnya berstatus sebagai kata yang mempunyai pola fonologis, gramatikal, dan semantik yang khusus menurut kaidah bahasa Indonesia.

Kata mubazir sering tidak dicermati penulisannya. Penulis masih saja menderetkan kata yang berlebihan dalam kalimat, padahal ketika dihilangkan tidak mengubah makna kalimat; misalnya agar supaya, oleh sebab karena, para hadirin, sejumlah data-data, dan lain-lain. 
Ketika menuliskan kata wantahan, penulis harus memperhatikan untuk memiringkannya; misalnya de facto dan de jure. Kata wantahan ini merupakan kata yang diserap dari bahasa asing dan digunakan dalam bentuk aslinya.

\section{Pemakaian Tanda Baca}

Tanda baca ini merupakan tanda yang dipakai dalam sistem ejaan. Dalam proses copyediting, perihal pemakaian tanda baca memerlukan kejelian penulis. Tanda baca itu meliputi tanda titik, tanda koma, tanda titik koma, tanda titik dua, tanda hubung, tanda pisah, tanda tanya, tanda seru, tanda elipsis, tanda petik, tanda petik tunggal, tanda kurung, tanda kurung siku, tanda garis miring, dan tanda penyingkat atau apostrof. Aturan pemakaian tanda baca dapat dilihat pada PUEBI. Hanya saja, dari sebanyak tanda baca itu, masih saja tanda elipsis terabaikan.

Tanda elipsis merupakan tanda baca berupa tiga titik yang diapit spasi (...); menggambarkan kalimat yang terputus-putus atau menunjukkan bahwa dalam suatu petikan ada bagian yang dihilangkan. Selain itu, yang masih sering terabaikan adalah pemakaian tanda petik tunggal, yaitu tanda baca ('...') yang mengapit petikan yang tersusun di dalam petikan lain. Tanda hubung dan tanda pisah, demikian juga, masih sering terabaikan pemakaiannya. Tanda hubung merupakan tanda garis (-) untuk menghubungkan unsur kata yang terpisah oleh pergantian baris, memisahkan bentuk ulang, atau menggabungkan unsur bentuk majemuk. Seringkali tanda hubung ini dirancukan dengan tanda pisah. Tanda baca yang membatasi penyisipan kata atau kalimat yang memberi penjelasan khusus di luar bangun kalimat adalah tanda pisah, bukan tanda hubung. Pemakaiannya secara lebih rinci diatur dalam PUEBI.

\section{Penulisan Unsur Serapan}

Dalam perkembangannya, bahasa Indonesia menyerap unsur dari berbagai bahasa, baik dari bahasa daerah, seperti bahasa Jawa, Sunda, dan Bali, maupun dari bahasa asing, seperti Bahasa Sanskerta, Arab, Portugis, Belanda, Cina, dan Inggris. Berdasarkan taraf integrasinya, unsur serapan dalam bahasa Indonesia dapat dibagi menjadi dua kelompok besar. Pertama, unsur asing yang belum sepenuhnya terserap ke dalam bahasa Indonesia, seperti force majeur, de facto, de jure, dan l'exploitation de l'homme par l'homme. Unsur-unsur itu dipakai dalam konteks bahasa Indonesia, tetapi cara pengucapan dan penulisannya masih mengikuti cara asing. Kedua, unsur asing yang penulisan dan pengucapannya disesuaikan dengan kaidah bahasa Indonesia. Dalam hal ini, penyerapan diusahakan agar ejaannya diubah seperlunya sehingga bentuk Indonesianya masih dapat dibandingkan dengan bentuk aslinya. Unsur serapan sesekali disebut sebagai unsur pinjaman, yaitu bunyi, fonem, unsur gramatikal, atau unsur leksikal yang diambil dari bahasa lain. Pemakaian unsur serapan secara detail dapat dilihat di PUEBI.

\section{Struktur Kalimat}

Dalam hal struktur kalimat, apalagi, selain tidak diterapkannya tata huruf, kata, tanda baca, unsur serapan, dan diksi, masih saja penulis lena berkalimat efektif. Kalimat adalah satuan bahasa terkecil, dalam wujud lisan atau tulisan, yang mengungkapkan pikiran yang utuh. Dalam wujud lisan, kalimat diucapkan dengan suara naik turun dan keras lembut, disela jeda dan diakhiri dengan intonasi akhir yang diikuti oleh kesenyapan, yang mencegah terjadinya perpaduan atau asimilasi bunyi ataupun proses morfologis lainnya. Dalam wujud tulisan berhuruf Latin, kalimat dimulai dengan huruf kapital dan diakhiri dengan tanda titik (.), tanda tanya (?), atau tanda seru (!); sementara itu, di dalamnya disertakan pula berbagai tanda baca, ..., dan spasi. Spasi adalah jarak antara huruf cetak dan antara baris kalimat. Tanda titik, tanda tanya, dan tanda seru sepadan dengan intonasi akhir, sedangkan tanda baca lain sepadan dengan jeda (Alwi dkk., 2014).

Kalimat efektif merupakan kalimat lengkap, yaitu kalimat yang mempunyai segala unsur yang paling sering dipakai dalam bahasa Indonesia, seperti kalimat yang mengandung subjek dan predikat. Kalimat karya ilamiah bukan kalimat menyimpang, yaitu kalimat yang maknanya dianggap aneh atau tidak lazim oleh bahasawan. Banyak hal dalam struktur kalimat yang harus diperhatikan dalam copyediting. Tidak semuanya dapat dinarasikan di sini. Sebagian kecil yang perlu juga diperhatikan adalah perihal konjungtor klausa.

Penulis karya ilmiah pada umumnya menulis kalimat dalam wujud lebih dari satu klausa. Klausa itu merupakan satuan gramatikal yang mengandung predikat dan berpotensi menjadi kalimat. Ketika 
mereka menulis kalimat yang mengandung dua klausa atau lebih, yang perlu diperhatikan adalah halhal yang menyangkut berbagai hubungan yang terdapat antara satu klausa dengan klausa yang lain di dalam kalaimat majemuk setara atau bertingkat.

Kalimat majemuk setara dan kalimat majemuk bertingkat mempunyai dua klausa atau lebih yang saling berhubungan. Ada dua cara untuk menghubungkan klausa dalam sebuah kalimat majemuk, yaitu dengan koordinasi dan subordinasi (Alwi dkk., 2014)

Koordinasi menggabungkan dua klausa atau lebih yang masing-masing mempunyai kedudukan yang setara dalam struktur konstituen kalimat. Hasilnya adalah satuan yang sama kedudukannya. Beberapa konjungtor untuk menyusun hubungan koordinasi adalah dan, atau, tetapi, serta, lalu, kemudian, lagi pula, hanya, padahal, sedangkan, baik ... maupun ..., tidak ... tetapi ..., dan bukan(nya) ... melainkan .... Konjungtor hubungan koordinasi ini selayaknya diperhatikan betul dalam proses copyediting. Selain itu, ada hubungan subordinasi.

Subordinasi menggabungkan dua klausa atau lebih sehingga terbukti kalimat majemuk yang salah satu klausanya menjadi bagian dari klausa yang lain. Jadi, klausa-klausa dalam kalimat majemuk yang disusun dengan cara subordinatif itu tidak mempunyai kedudukan yang setara. Hubungan antarklausa bersifat hierarkhis. Oleh karena itu, kalimat majemuk yang disusun dengan cara subordinatif ini disebut kalimat majemuk bertingkat.

Dalam proses copyediting, perlu diperhatikan apakah klausa subordinatif itu merupakan klausa nominal karena menduduki fungsi yang biasa diduduki oleh nomina. Jika dalam posisi demikian, konjungtor yang digunakan, antara lain, adalah bahwa, apakah (atau tidak), dan di mana. Misalnya,

a. Saya dengar bahwa dia akan berangkat besok.

b. Saya tidak yakin apakah dia akan datang atau tidak.

c. Saya tahu di mana anak itu tinggal.

Contoh yang lain adalah klausa subordinatif yang merupakan klausa adverbial. Yang perlu dicermati dalam copyediting adalah penggunaan konjungtor klausa adverbial. Ada banyak konjungtor yang digunakan untuk menggabungkan klausa adverbial dengan klausa utama: (a) konjungtor waktu: setelah, sesudah, sebelum, sehabis, sejak, selesai, ketika, tatkala, sewaktu, sementara, sambil, seraya, selagi, selama, sehingga, sampai; (b) konjungtor syarat: jika, jikalau, kalau, asal(kan), bila, manakala; (c) konjungtor pengandaian: andaikan, seandainya, andaikata, sekiranya; (d) konjungtor tujuan: agar, supaya, biar; (e) konjungtor konsesif: biarpun, meski(pun), sungguhpun, sekalipun, walau(pun), kendati(pun); (f) konjungtor perbandingan atau kemiripan: seakan-akan, seolah-olah, sebagaimana, seperti, sebagai, bagaikan, laksana, daripada, alih-alih, ibarat; (g) konjungtor sebab atau alasan: sebab, karena, oleh karena; (h) konjungtor hasil atau akibat: sehingga, sampai-(sampai); (i) konjungtor cara: dengan, tanpa; (j) konjungtor alat: dengan, tanpa.

Yang juga masih perlu dicermati dalam copyediting, antara lain, adalah konjungtor korelatif. Konjungtor korelatif adalah konjungtor yang menghubungkan dua kata, frasa, atau klausa yang memiliki status sintaksis yang sama. Konjungtor korelatif ini terdiri atas dua bagian yang dipisahkan oleh salah satu kata, frasa, atau klausa yang dihubungkan; misalnya baik ... maupun ...; tidak hanya ..., tetapi juga ...; bukan hanya ..., melainkan juga ...; demikian ... sehingga ...; sedemikian rupa ... sehingga ...; apa(kah) ... atau ...; entah ... entah ...; jangankan ..., ... pun ....

\section{Aspek-Aspek Lain}

Hal-hal yang berkait dengan kaidah kebahasaan di atas, tidak terlepas pula dari aspek-aspek yang diedit berikut ini. Aspek-aspek lain ini merupakan kelanjutan dari aspek-aspek yang perlu diedit dalam proses pengeditan yang cerdas. Aspek-aspek itu, antara lain, adalah (a) keterbacaan atau kejelasan, (b) konsistensi atau ketaatasasan, (c) kebahasaan, (d) ketelitian, (e) legalitas dan kesopanan, dan (f) rincian.

Proses pengeditan yang cerdas merupakan proses pengeditan yang sempurna karena ketajaman pengeditannya. Kata cerdas mempunyai arti sempurna perkembangan akal budinya (untuk berpikir, mengerti, dan sebagainya). Editor bahasa yang cerdas merupakan editor bahasa yang tajam editannya dan yang sempurna editannya. 
Akan tetapi, karena terbatasnya media diskusi, hal-hal yang tertera di atas ini belum dibicarakan. Salah satu contoh perihal ketidakterbacaan atau ketidakjelasan kalimat karya ilmiah adalah sebagai berikut. "Selain itu salah satu motif yang diperkirakan juga mempengaruhi pemilihan plot yang lebih kompleks dan cara penyampaian yang tidak langsung pada intinya seperti penyampaian cerita ini secara lisan di kalangan masyarakat biasa adalah adanya tindakan untuk membukukan cerita ini dalam sebuah karya yang ditujukan untuk seorang pakar yang dalam hal ini dianggap sebagai orang penting sehingga pengarang secara tidak langsung memiliki kesadaran untuk membuatnya lebih layak untuk dibukukan."

Kalau sudah sampai pada contoh seperti tertera di atas, yaitu kalimat yang tidak berketerbacaan atau tidak berkejelasan, diseyogiakan penulis, yang pada proses copyediting tulisan sendiri berperan sebagai editor bahasa, tidak meng-copyediting-nya sendiri, tetapi memerlukan bantuan editorbahasa lain.

\section{PENUTUP}

Copyediting dapat dilakukan dengan efektif dan efisien ketika memenuhi aspek-aspek yang diedit dan dilakukan dengan proses pengeditan yang cerdas. Proses pengeditan yang cerdas merupakan proses pengeditan yang sempurna sesuai dengan kaidah kebahasaan beserta teknik penulisan ilmiahnya.

Copyediting yang dilakukan dengan efektif merupakan penyuntingan naskah yang ada efeknya, ada akibatnya, ada pengaruhnya, atau ada kesannya. Copyediting ini dapat membawa hail atau berhasil guna setelah ada tindakan penyuntingan.

Copyediting yang dilakukan dengan efisien merupakan penyuntingan naskah yang tepat atau sesuai dengan kaidah kebahasaan ketika pengerjaan suntingan itu berlangsung. Ada ketepatan atau kesesuaian mengerjakan penyuntingan dengan tidak membuang-buang waktu, tenaga, dan biaya. Editor bahasa mampu menjalankan penyuntingan dengan tepat dan cermat sehingga hasil suntingannya itu berdaya guna dan bertepat guna.

\section{DAFTAR RUJUKAN}

Alwi, Hasan dkk. 2014. Tata Bahasa Baku Bahasa Indonesia. Jakarta: Balai Pustaka.

Eneste, Pamusuk. 2005. Buku Pintar Penyuntingan Naskah. Jakarta: Gramedia Pustaka Utama.

Kamus Besar Bahasa Indonesia. 2019. Online. Jakarta: Badan Pengembangan dan Pembinaan Bahasa Indonesia, Kementerian Pendidikan dan Kebudayaan.

Pedoman Umum Ejaan Bahasa Indonesia. 2016. Jakarta: Badan Pengembangan dan Pembinaan Bahasa, Kementerian Pendidikan dan Kebudayaan.

Rifai, Mien A. 2005. Pegangan Gaya Penulisan, Penyuntingan, dan Penerbitan, Yogyakarta: Gadjah Mada University Press.

Sugihastuti. 2016. Praktik Penyuntingan Kalimat. Yogyakarta: Pustaka Pelajar. 2016. Editor Bahasa. Yogyakarta: Pustaka Pelajar.

Trim, Bambang. 2005. Memahami Copyediting. Jakarta: Ikapi DKI Jakarta. 